\title{
Purification, Visualization and Characterization of the Sexual Agglutinins of the Green Alga Chlamydomonas moewusii yapensis
}

\author{
By MARIEKE R. SAMSON, FRANS M. KLIS, * KEES J. CRABBENDAM, \\ PIET VAN EGMOND AND HERMAN VAN DEN ENDE \\ Department of Plant Physiology, University of Amsterdam, Kruislaan 318, Amsterdam, \\ The Netherlands
}

(Received 9 April 1987; revised 11 June 1987)

\begin{abstract}
Purification of the sexual agglutinins of both mating types of Chlamydomonas moewusii yapensis ( $=C$. moewusii syngen II) was achieved by a three-step procedure. Electron microscopy showed both agglutinins to be long, linear molecules. The $\mathrm{mt}^{+}$agglutinin was a rigid molecule with one bulbous end and an average length of $251 \mathrm{~nm}$. The $\mathrm{mt}^{-}$agglutinin was longer (average length $349 \mathrm{~nm}$ ), had a more flexible conformation and lacked a bulbous end. The $M_{\mathrm{r}}$ was estimated to be $1.0 \times 10^{6}$ for the $\mathrm{mt}^{+}$and $1.2 \times 10^{6}$ for the $\mathrm{mt}^{-}$agglutinin. The $\mathrm{mt}^{-}$agglutinin had a very high content of hydroxyproline $(41 \%)$ and serine $(14 \%)$; the $\mathrm{mt}^{+}$agglutinin had a high content of glycine, serine and hydroxyproline $(18,16$ and $12 \%$, respectively). The main sugars in the agglutinins of both mating types were arabinose and galactose. The carbohydrate portion represented about $40 \%$ of the $M_{\mathrm{r}}$ in both agglutinins. The biological activity of both agglutinins could be destroyed by periodate treatment (although their sensitivities differed), indicating the involvement of carbohydrate residues. A differential susceptibility for exoglycosidases was observed: enzymic removal of terminal glucose residues abolished the biological activity of the $\mathrm{mt}^{+}$agglutinin only, while removal of mannose residues selectively inactivated the $\mathrm{mt}^{-}$ agglutinin. The similarities in form and composition of the agglutinins of several Chlamydomonas species suggest that these recognition molecules have a common ancestry, and that the species barriers are at least partially dependent on differences in the carbohydrate sidechains.
\end{abstract}

\section{INTRODUCTION}

Many recognition reactions in plants involve highly specific macromolecules at the surface of the cells. The sexual agglutination process of Chlamydomonas represents an excellent model of such a cellular recognition process (Van den Ende, 1985). Chlamydomonas is a biflagellate, unicellular green alga. Under nutrient-limited conditions, the vegetatively growing cells differentiate into gametes. Gametes of opposite mating type, referred to as $\mathrm{mt}^{+}$and $\mathrm{mt}^{-}$, recognize and adhere to each other via their flagella, forming large, twitching clumps. This flagellar adhesion triggers a number of subsequent reactions that lead to the sorting out of pairs, the fusion of two cells of opposite mating type and eventually to the formation of a zygote. The agglutination reaction itself is mediated by high- $M_{\mathrm{r}}$ glycoproteins at the flagellar surface, the socalled agglutinins, that are recognized by the partner cell (Van den Ende, 1985). The high specificity of the sexual recognition reaction, both for mating type and species, may be attributed to the specific features of the agglutinins themselves; this makes a comparison of the agglutinins of different mating type and species of great interest.

The isolation and partial characterization of the $\mathrm{mt}^{+}$and $\mathrm{mt}^{-}$agglutinin of Chlamydomonas reinhardtii have been reported by Adair et al. (1982), Collin-Osdoby \& Adair (1985) and Saito \&

Abbreviations: HPGF, high-performance gel filtration; mt, mating type.

$0001-4135$ (C) 1987 SGM 
Matsuda (1984). Both agglutinins of $C$. eugametos, a species that cannot sexually interact with $C$. reinhardtii, have also been purified, and their composition and other properties have been determined (Samson et al., 1987). Both the C. reinhardtii and the C. eugametos agglutinins appear to be long, linear glycoproteins of high molecular mass and have a high content of hydroxyproline and serine (Collin-Osdoby \& Adair, 1985; Samson et al., 1987).

Here we report the purification, amino acid and sugar composition, morphology and several chemical and physical properties of the sexual agglutinins of Chlamydomonas moewusii yapensis ( =C. moewusii syngen II). This species is closely related to C. eugametos and C. moewusii syngen I, but cannot sexually interact with them (Wiese \& Jones, 1963) or with $C$. reinhardtii. We show that the agglutinins of $C$. moewusii yapensis are also long, linear glycoproteins and that, as with those of C. reinhardtii and C. eugametos (Collin-Osdoby \& Adair, 1985; Samson et al., 1987) the carbohydrate part of the molecule appears to be important for their biological activity.

\section{METHODS}

Cell cultures. Chlamydomonas moewusii yapensis strains UTEX $792\left(\mathrm{mt}^{+}\right)$and UTEX $793\left(\mathrm{mt}^{-}\right)$from the Algal Collection of the University of Texas at Austin, USA, were cultivated in Petri dishes on agar-containing medium under a $12 \mathrm{~h}$ light/ $12 \mathrm{~h}$ dark regimen. Gamete suspensions were obtained by flooding 3- to 4-week-old cultures with distilled water just before the dark period and harvesting the cells at the beginning of the next light period.

Extraction and purification of the agglutinins. Extractions with $0 \cdot 1 \%(\mathrm{w} / \mathrm{v})$ Triton $\mathrm{X}-100$ were performed as described by Klis et al. (1985). Biological activity in solution was assayed by the semi-quantitative method described by Musgrave et al. (1981). The agglutinins were purified essentially as described by Samson $e t$ al. (1987). Biologically active solutions were fractionated by gel filtration over Sepharose 4B-Cl (Pharmacia, $70 \times 2.5 \mathrm{~cm}$ ). The column was eluted with $10 \mathrm{mM}-\mathrm{Tris} / \mathrm{HCl}, \mathrm{pH} 7 \cdot 5$, at a flow rate of $15 \mathrm{ml} \mathrm{h}^{-1}$, and fractions of $16 \mathrm{ml}$ were collected. The biological activity was found in the void volume. Appropriate fractions were applied to a $9.2 \times 2.5 \mathrm{~cm}$ column packed with DEAE-Trisacryl M (anion exchanger, LKB), equilibrated in $10 \mathrm{mM}-\mathrm{Tris} / \mathrm{HCl}$, $\mathrm{pH} 7 \cdot 5$. The $\mathrm{mt}^{-}$and $\mathrm{mt}^{+}$agglutinins were eluted with, respectively, a $0-150 \mathrm{~mm}$ and a $100-250 \mathrm{~mm}$ linear gradient of $\mathrm{NaCl}$ in buffer. The flow rate was $12 \mathrm{ml} \mathrm{h}^{-1}$ and fractions of $5.5 \mathrm{ml}$ were collected. The $\mathrm{mt}^{-}$agglutinin eluted at $50 \mathrm{~mm}-\mathrm{NaCl}$ and the $\mathrm{mt}^{+}$agglutinin at $120 \mathrm{~mm}-\mathrm{NaCl}$. Appropriate fractions were desalted by gel filtration and concentrated using a Centricon PD30 (Amicon). Final purification was achieved by high-performance gel filtration (HPGF) of agglutinin-containing fractions, using an LKB apparatus with a $600 \times 7.5 \mathrm{~mm}$ G6000-PW gel filtration column and a $75 \times 7.5 \mathrm{~mm}$ TSK-PWH guard column (Toyo Soda Manufacturing Co.). Samples of $200 \mu \mathrm{l}$ were injected and eluted with $0.1 \mathrm{M}-\mathrm{Na}_{2} \mathrm{SO}_{4}$ in $10 \mathrm{~mm}$-sodium phosphate, $\mathrm{pH} 7 \cdot 4$, at a flow rate of $30 \mu \mathrm{min}^{-1}$. The temperature was $18-20^{\circ} \mathrm{C}$. Absorbance at $206 \mathrm{~nm}$ was measured and $10-\mathrm{min}$ fractions were collected. The void volume was determined with aggregated proteins and the total volume with histidine, [ ${ }^{32} \mathrm{P}$ ]phosphate and water (negative absorbance peak: at $206 \mathrm{~nm}$ water has a lower absorbancy than the eluent).

Calculation of $M_{\mathrm{r}}$. The $M_{\mathrm{r}}$ values of the agglutinins were determined by the equation given by Siegel \& Monty (1966). This states that the $M_{\mathrm{r}}$ of a molecule is proportional to its Stokes' radius and sedimentation coefficient and also depends on the partial specific volume. From their behaviour in HPGF the Stokes' radii of the sexual agglutinins were estimated as described by Samson et al. (1987). The sedimentation coefficients were determined using sucrose gradient centrifugation as described by Klis et al. (1985). The partial specific volume of both agglutinins was estimated from their composition according to Perkins et al. (1981) and Cohn \& Edsall (1943).

Electron microscopy. Purified sexual agglutinins were visualized by negative staining as described by Smith $\&$ Seegan (1984) with minor modifications (Crabbendam et al., 1987).

Analyses. Purified agglutinins were hydrolysed for $24 \mathrm{~h}$ at $110^{\circ} \mathrm{C}$ under $\mathrm{N}_{2}$ in constant-boiling $\mathrm{HCl}$. The hydrolysates were used for amino acid analysis on an LKB 4151 Alpha-plus amino acid analyser. They were also used for determination of hydroxyproline according to Drozdz et al. (1976), using the modification of Samson et al. (1987).

Methanolysis of the glycoprotein was carried out under $\mathrm{N}_{2}$ in $1 \mathrm{M}$-methanolic $\mathrm{HCl}$ for $24 \mathrm{~h}$ at $85^{\circ} \mathrm{C}$. Sugars were determined by gas chromatography of the trimethylsilyl derivatives of the methanolysed sugars (Clamp, 1977). Mannitol was used as the internal standard.

Enzyme incubations. Incubation conditions were as follows : $\alpha$-galactosidase (EC 3.2.1.22), $0 \cdot 1 \mathrm{U}$ for $3 \mathrm{~h}$ at $22^{\circ} \mathrm{C}$ and pH 5; $\alpha$-glucosidase (EC 3.2.1.20), $1 \mathrm{U}$ for $22 \mathrm{~h}$ at $22^{\circ} \mathrm{C}$ and $\mathrm{pH} 6 ; \alpha$-mannosidase (EC 3.2.1.24), 0.2 $\mathrm{U}$ for $22 \mathrm{~h}$ at $22^{\circ} \mathrm{C}$ and $\mathrm{pH} 5$; glucose oxidase (EC 1.1.3.4), $2 \mathrm{U}$ for $3 \mathrm{~h}$ at $22^{\circ} \mathrm{C}$ and $\mathrm{pH} \mathrm{7;} \mathrm{sulphatase,} \mathrm{from} \mathrm{Helix}$ pomatia, $1 \mathrm{mg} \mathrm{ml}^{-1}$ for $2 \mathrm{~h}$ at $25^{\circ} \mathrm{C}$ and pH 5; phosphatase, $0.4 \mathrm{mg} \mathrm{ml}^{-1}$ for $2 \mathrm{~h}$ at $25^{\circ} \mathrm{C}$ and pH $5 ; \operatorname{trypsin}, 0.05 \%$ $(\mathrm{w} / \mathrm{v})$ for $3 \mathrm{~h}$ at $22^{\circ} \mathrm{C}$ and $\mathrm{pH} 7$; pronase, $0.02 \mathrm{U}$ for $24 \mathrm{~h}$ at $22^{\circ} \mathrm{C}$ and $\mathrm{pH} 4.5$ and 7.5 . Phosphatase was obtained from Boehringer Mannheim, and pronase from Calbiochem; all other enzymes were from Sigma. 
RESULTS

\section{Purification of the agglutinins}

A three-step procedure was used. The first step consisted of gel filtration of detergent-free gamete extracts over Sepharose 4B-Cl (exclusion limit for globular proteins $M_{\mathrm{r}} 2 \times 10^{7}$ ), which resulted in the elution of biologically active material in the void volume. Since the bulk of protein eluted later, this fractionation gave a 5- to 10 -fold purification of the agglutinins. To analyse the biologically active fractions we used HPGF; the column used separated molecules with an apparent $M_{\mathrm{r}}$ from less than $2 \times 10^{4}$ to about $10^{8}$. HPGF revealed several protein components (Fig. 1). Most protein in both the $\mathrm{mt}^{-}$and the $\mathrm{mt}^{+}$preparation eluted at about $19.5 \mathrm{ml}$ and several minor peaks and shoulders were detected. When these fractions were analysed by SDS-PAGE (results not shown), about five carbohydrate-containing bands (as judged by staining with periodic acid-Schiff reagent) could be detected in the high- $M_{\mathrm{r}}$ region of a $4 \%(\mathrm{w} / \mathrm{v})$ polyacrylamide gel.

The components present in the void volume of the Sepharose $4 \mathrm{~B}-\mathrm{Cl}$ column were further fractionated by anion-exchange chromatography on DEAE-Trisacryl $\mathrm{M}$ at $\mathrm{pH} 7.5$. The gel was first eluted with $10 \mathrm{~mm}$-Tris/ $\mathrm{HCl}(\mathrm{pH} 7.5)$ followed by a salt gradient in this buffer. For the $\mathrm{mt}^{+}$ preparation a $100-250 \mathrm{~mm}-\mathrm{NaCl}$ gradient was used and the biological activity eluted at about $120 \mathrm{~mm}-\mathrm{NaCl}$. Using a $0-150 \mathrm{~mm}-\mathrm{NaCl}$ gradient for the $\mathrm{mt}^{-}$preparations, elution of the $\mathrm{mt}^{-}$ biological activity occurred at about $50 \mathrm{~mm}-\mathrm{NaCl}$. Analysis of the biologically active fractions by HPGF gave a relatively simple profile (Fig. 2). The $\mathrm{mt}^{+}$preparation showed a major protein peak at $18.2 \mathrm{ml}$; only the fractions corresponding with this peak showed biological activity. A minor peak could be detected at $21.0 \mathrm{ml}$ and a minute shoulder at about $19.5 \mathrm{ml}$. The $\mathrm{mt}^{-}$ preparation showed a major protein peak at $17.9 \mathrm{ml}$, which comigrated with the biological activity. The peak was well separated from the other, inactive peaks at 20.2 and $21.0 \mathrm{ml}$.

The fractions containing most biological activity were collected and run again through the same column. This resulted in a single, symmetrical protein peak; the $\mathrm{mt}^{+}$agglutinin eluted at $18.2 \mathrm{ml}$ and the $\mathrm{mt}^{-}$agglutinin at $17.9 \mathrm{ml}$. This material showed only one carbohydrate-stainable band on PAGE (results not shown). Examination by electron microscopy showed a homogeneous population of long, linear molecules (see below).

\section{Electron microscopy}

Examination of the purified agglutinins by electron microscopy, using the negative staining, 'pleated sheet' method of Smith \& Seegan (1984), showed long, linear molecules (Fig. 3). The $\mathrm{mt}^{+}$agglutinins were visualized as rather rigid molecules with a length of $251 \pm 12 \mathrm{~nm}(n=49)$, and slightly bulbous at one end. The $\mathrm{mt}^{-}$agglutinin appeared to be a considerably longer, more flexible molecule with a length of $349 \pm 31 \mathrm{~nm}(n=24)$. It showed a somewhat corkscrew-like appearance, without a bulbous end. Both agglutinins seemed to have a uniform width.

\section{Calculation of the $M_{\mathrm{r}}$ of the agglutinins}

Since most conventional methods for $M_{\mathrm{r}}$ determination (SDS-PAGE and gel filtration) are not suited for such highly asymmetrical glycoproteins as the Chlamydomonas agglutinins, we used the fact that the $M_{\mathrm{r}}$ is proportional to the Stokes' radius and the sedimentation coefficient and depends on the partial specific volume of a molecule (Siegel \& Monty, 1966). We have shown (Samson et al., 1987) that the theoretically predicted relation between behaviour in gel filtration and Stokes' radius could be confirmed for high- $M_{\mathrm{r}}$ compounds of different composition and form in our HPGF system. From the elution position of the agglutinins from the HPGF column we estimated the Stokes' radius to be $36 \mathrm{~nm}$ and $37 \mathrm{~nm}$ for the $\mathrm{mt}^{+}$and the $\mathrm{mt}^{-}$agglutinin, respectively. The sedimentation coefficients of the agglutinins were determined by sucrose gradient centrifugation : 7.9S for the $\mathrm{mt}^{+}$, and $9.6 \mathrm{~S}$ for the $\mathrm{mt}^{-}$agglutinin. The partial specific volumes were calculated using the amino acid and sugar composition of the agglutinins (Table 1) according to Perkins et al. (1981) and Cohn \& Edsall (1943); the value was $0.68 \mathrm{ml} \mathrm{g}^{-1}$ for both agglutinins. Using these data we calculated the $M_{\mathrm{r}}$ for the $\mathrm{mt}^{+}$agglutinin to be $1.0 \times 10^{6}$, and that for the $\mathrm{mt}^{-}$agglutinin to be $1.2 \times 10^{6}$. 


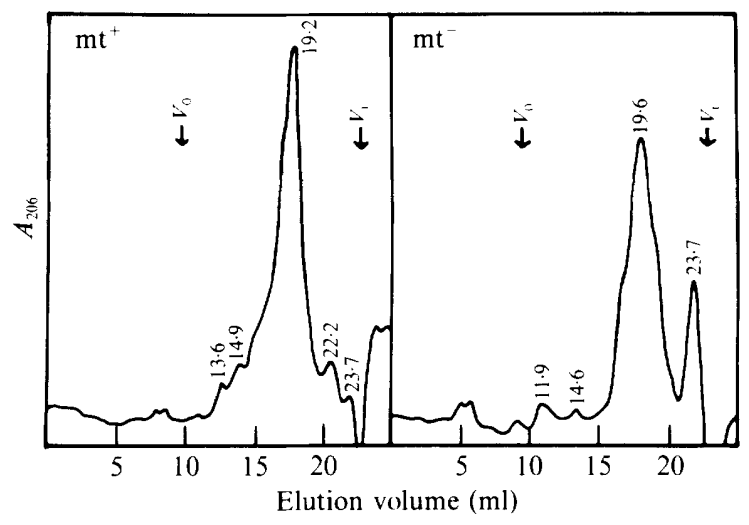

Fig. 1. Separation by HPGF (G6000-PW column) of the high- $M_{\mathrm{r}}$ compounds in $\mathrm{mt}^{+}$and $\mathrm{mt}^{-}$extracts. The void volume fractions eluting from a Sepharose $4 \mathrm{~B}-\mathrm{Cl}$ column were analysed. Full scale represents 0.05 absorbance units. Elution volumes $(\mathrm{ml})$ are given next to the corresponding peaks.

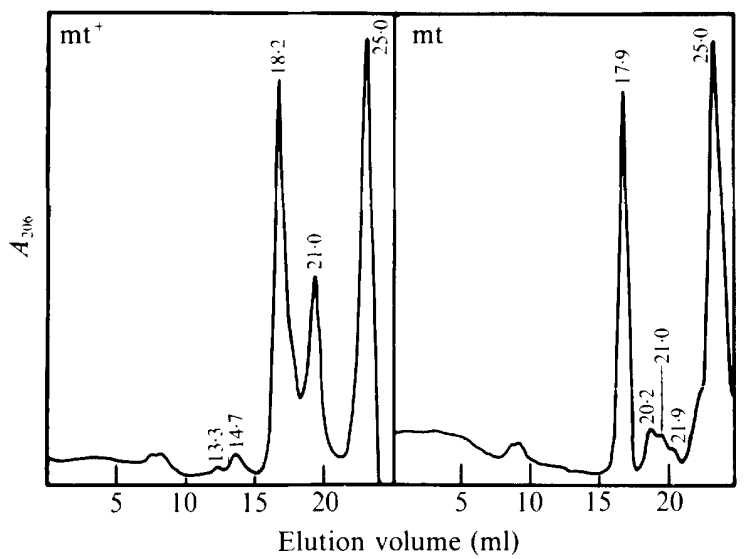

Fig. 2. HPGF profile (G6000-PW column) of biologically active fractions eluting from the DEAETrisacryl M column. Full scale represents 0-05 absorbance units. Elution volumes ( $\mathrm{ml}$ ) are given next to the corresponding peaks.

\section{Amino acid and carbohydrate composition of the agglutinins}

Table 1 shows the amino acid and sugar composition of the sexual agglutinins. In both agglutinins hydroxyproline and serine were abundant amino acids. Both these amino acids can be points of attachment of $O$-glycosidically linked carbohydrate chains. In the mt ${ }^{-}$agglutinin an extremely high content of hydroxyproline was found using two independent methods: amino acid analysis and a colorimetric hydroxyproline assay.

Arabinose represented about half the total sugar residues of both agglutinins. A high galactose content was also observed. The sugar composition of the agglutinins of the two mating types was remarkably similar. The absence of detectable $N$-acetylglucosamine in both agglutinins may indicate that $N$-linked sugar chains are not present in these glycoproteins and that only $O$ glycosidic linkages occur.

\section{Comparison of some properties of the $\mathrm{mt}^{+}$and $\mathrm{mt}^{-}$agglutinins}

In Table 2 we present some of the properties of the $\mathrm{mt}^{+}$and $\mathrm{mt}^{-}$agglutinins that might be relevant for our understanding of the agglutinin-mediated recognition reaction. From the electron micrographs it can be concluded that both the agglutinins are long, linear molecules, 


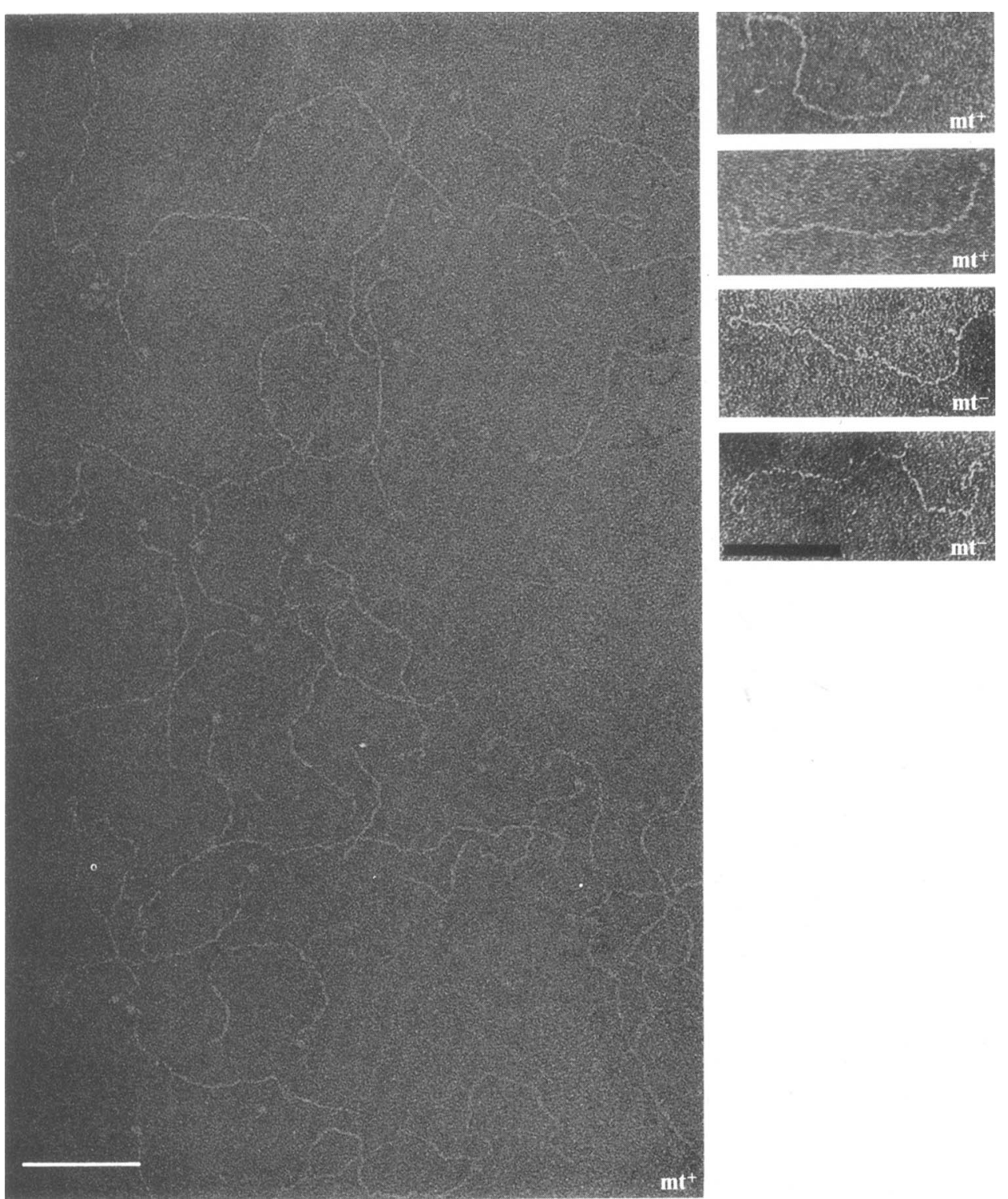

Fig. 3. Electron micrographs of purified $\mathrm{mt}^{+}$and $\mathrm{mt}^{-}$agglutinins after negative staining using the 'pleated sheet' technique. The large photograph shows a field containing numerous $\mathrm{mt}^{+}$agglutinin molecules. Selected $\mathrm{mt}^{+}$and $\mathrm{mt}^{-}$agglutinin molecules are shown on the right. The average lengths of the $\mathrm{mt}^{+}$and $\mathrm{mt}^{-}$agglutinins were $251 \mathrm{~nm}$ and $349 \mathrm{~nm}$, respectively. Bars, $100 \mathrm{~nm}$.

differing, however, in length and form. Their asymmetric shape explains the discrepancy between their behaviour on gel filtration columns as apparently extremely large molecules and their relatively low sedimentation coefficients. A clear difference between the $\mathrm{mt}^{+}$and $\mathrm{mt}^{-}$ agglutinin was their elution from the anion exchange column: the $\mathrm{mt}^{-}$agglutinin was only loosely bound to DEAE-Trisacryl at $\mathrm{pH} \mathrm{7.5,} \mathrm{while} \mathrm{the} \mathrm{mt}^{+}$agglutinin showed a firmer interaction.

The agglutinins differed in the susceptibility of their biological activity to various chemical treatments and enzyme incubations. Denaturing agents such as guanidine thiocyanate and SDS, and also incubation in $10 \mathrm{~mm}$-sodium acetate at $\mathrm{pH} \mathrm{4}$, inactivated the $\mathrm{mt}^{+}$, but not the $\mathrm{mt}^{-}$ 
Table 1. Amino acid and carbohydrate compositions of the sexual agglutinins of

C. moewusii yapensis

\begin{tabular}{|c|c|c|c|c|c|}
\hline & \multicolumn{2}{|c|}{$\begin{array}{l}\text { Amino acids } \\
\text { (residues per } \\
100 \text { residues) }\end{array}$} & & \multicolumn{2}{|c|}{$\begin{array}{c}\text { Sugars } \\
\text { (residues per } \\
100 \text { residues) }\end{array}$} \\
\hline & $\mathrm{mt}^{+}$ & $\mathrm{mt}^{-}$ & & $\mathrm{mt}^{+}$ & $\mathrm{mt}^{-}$ \\
\hline $\operatorname{Ser}(P)$ & 2 & 1 & Ara & 46 & 59 \\
\hline Asx & 8 & 3 & Rha & 4 & 3 \\
\hline Нyp & 12 & 41 & $\mathrm{Xyl}$ & 9 & 6 \\
\hline Thr & 5 & 5 & Man & 5 & 3 \\
\hline Ser & 16 & 14 & $\mathrm{Gal}$ & 29 & 26 \\
\hline Glx & 9 & 4 & Glc & 7 & 3 \\
\hline Gly & 18 & 8 & GlcNAc & ND & ND \\
\hline Ala & 8 & 5 & & & \\
\hline Val & 3 & 1 & & & \\
\hline Ile & tr. & tr. & & & \\
\hline Leu & 6 & 10 & & & \\
\hline Tyr & 2 & 1 & & & \\
\hline Phe & 2 & 1 & & & \\
\hline Lys & 5 & 3 & & & \\
\hline $\mathrm{His}$ & 1 & 1 & & & \\
\hline Arg & 3 & 2 & & & \\
\hline
\end{tabular}

Table 2. Comparison of some properties of the $\mathrm{mt}^{+}$and $\mathrm{mt}^{-}$agglutinins of $\mathrm{C}$. moewusii yapensis

Property

Elution from Sepharose 4B-Cl*

Elution from DEAE-Trisacryl $(\mathrm{pH} \mathrm{7.5)}$

HPGF†

Stokes' radius

Sedimentation coefficient

Form

Length

$M_{\mathrm{r}}$

Sugar : protein $(w / w)$

$M_{\mathrm{r}}$ of protein part

Major amino acids

Major sugars

GlcNAc detectable

Concanavalin A binding

Reduction of biological activity by:

$\alpha$-Galactosidase

$\alpha$-Glucosidase

Glucose oxidase

$\alpha$-Mannosidase

Periodate (10 mM)

Phosphatase

Sulphatase

Phosphatase + periodate $(10 \mathrm{~mm}) \ddagger$

Sulphatase + periodate $(10 \mathrm{~mm})_{*}^{*}$

Trypsin

Pronase

Guanidine thiocyanate (2 $\mathrm{M}) \S$

SDS $(1 \%, w / v) \S$

Sodium acetate $(10 \mathrm{~mm}, \mathrm{pH} 4) \S$

Sodium carbonate $(20 \mathrm{~mm}, \mathrm{pH} 10) \S$ $\mathrm{mt}^{+}$

Void volume

$120 \mathrm{mM}-\mathrm{NaCl}$

$K_{\mathrm{av}}=0.54$

$36 \mathrm{~nm}$

$7.9 \mathrm{~S}$

Rod shaped, one bulbous end, rigid

$251 \mathrm{~nm}$

$1.0 \times 10^{6}$

$40: 60$

$6 \times 10^{5}$

Gly, Ser, Hyp

Ara, Gal

No

Yes

No

Yes

No

No

Yes

ND

ND

ND

ND

No

Yes

Yes

Yes

Yes

Yes $\mathrm{mt}^{-}$

Void volume

$50 \mathrm{~mm}-\mathrm{NaCl}$

$K_{\mathrm{av}}=0 \cdot 52$

$37 \mathrm{~nm}$

9.6S

Rod shaped, no bulbous

end, flexible

$349 \mathrm{~nm}$

$1.2 \times 10^{6}$

$35: 65$

$7.5 \times 10^{5}$

Hyp, Ser

Ara, Gal

No

Yes

No

No

No

Yes

No

No

No

Yes

Yes

No

Yes

No

No

No

Yes

ND, Not determined.

* The exclusion limit of Sepharose 4B-Cl is for globular macromolecules $M_{\mathrm{r}} 2 \times 10^{7}$.

$\uparrow$ The exclusion limit of the HPGF is for globular macromolecules $M_{\mathrm{r}} 10^{8}$.

$\$$ The enzyme incubation was followed by incubation with periodate for $1 \mathrm{~h}$ at $\mathrm{pH} 4$ and $22^{\circ} \mathrm{C}$.

$\S$ Incubation for $3 \mathrm{~h}$ at room temperature. 
agglutinin. Incubation at $\mathrm{pH} 10$ abolished both biological activities, possibly by $\beta$-elimination of $O$-glycosidically linked sugar chains, suggesting that these sugar residues are responsible for the biological activity. Treatment with periodate showed remarkable differences: a very mild treatment ( $10 \mathrm{~mm}$ at room temperature for $60 \mathrm{~min}$ at $\mathrm{pH}$ 6) abolished only the activity of the $\mathrm{mt}^{+}$ agglutinin, but the activity of the $\mathrm{mt}^{-}$agglutinin seemed to be insensitive to periodate, even in harsher conditions ( $20 \mathrm{~mm}$ at room temperature for $30 \mathrm{~h}$ at $\mathrm{pH} 4$ ). However, after treatment with sulphatase and phosphatase, which in itself did not affect the biological activity, periodate treatment did destroy the $\mathrm{mt}^{-}$activity. This might indicate that sugar residues are involved in the biological activity of both agglutinins, but that sulphate and phosphate substitution inhibits direct periodate attack of carbohydrate moieties in the $\mathrm{mt}^{-}$agglutinin. The susceptibility of the agglutinins to exoglycosidases also differed: $\alpha$-glucosidase eliminated the biological activity of the $\mathrm{mt}^{+}$, but not of the $\mathrm{mt}^{-}$agglutinin, while $\alpha$-mannosidase reduced the biological activity of the $\mathrm{mt}^{-}$, but not of the $\mathrm{mt}^{+}$agglutinin.

\section{DISCUSSION}

In this article we report the purification of the sexual agglutinins of $C$. moewusii yapensis. The purity of the agglutinins was established by their elution as single protein peaks in HPGF, by the presence of only one sugar-stainable band on SDS-PAGE, and by the fact that electron microscopy showed a homogeneous population of macromolecules. The purification steps were essentially the same as adopted for the purification of the agglutinins of C. eugametos (Samson et al., 1987) and we presume that this procedure can also be used for purifying agglutinins of other Chlamydomonas species.

Electron microscopy showed that both agglutinins are long, linear molecules. This structure has also been reported for other Chlamydomonas agglutinins (Goodenough et al., 1985; Klis et $a l ., 1985)$. The agglutinins of $C$. reinhardtii are both rather rigid, rod-shaped molecules with a total length of about $260 \mathrm{~nm}$, and possess determinate domains such as a bulbous end, a shaft and a hook region (Goodenough et al., 1985). The agglutinins of $C$. eugametos are also rodshaped but they are somewhat longer ( $328 \mathrm{~nm}$ for the $\mathrm{mt}^{+}, 345 \mathrm{~nm}$ for the $\mathrm{mt}^{-}$agglutinin), and no bulbous end was seen in the $\mathrm{mt}^{-}$agglutinin, which instead displayed a number of flexible regions at fixed positions (Crabbendam et al., 1987). The agglutinins of $C$. moewusii yapensis show even larger differences between the mating types, the $\mathrm{mt}^{+}$agglutinin having one bulbous and one tapered end and a length of about $250 \mathrm{~nm}$, and the $\mathrm{mt}^{-}$agglutinin having two tapered ends, a length of about $350 \mathrm{~nm}$ and a much less rigid conformation. However, unlike the $\mathrm{mt}^{-}$ agglutinin of $C$. eugametos, the points of flexion in the molecule did not appear to occur at set positions. The agglutinins of $C$. moewusii yapensis can be considered as hydroxyproline-rich glycoproteins: the $\mathrm{mt}^{-}$agglutinin has an exceptionally high content of hydroxyproline, as only found until now in extensins, glycoproteins which are structural compounds in the primary wall of higher plants (Lamport, 1980). One might presume that the agglutinins also possess a stable polyproline II helix conformation, by analogy with cell wall glycoproteins from higher plants (Van Holst \& Varner, 1984) and from C. reinhardtii (Homer \& Roberts, 1979); this has already been suggested for other agglutinins, which have hydroxyproline contents comparable with that of the $\mathrm{mt}^{+}$agglutinin of C. moewusii yapensis (Goodenough et al., 1985; Samson et al., 1987). The bulbous end of the $\mathrm{mt}^{+}$agglutinin is possibly its only globular domain. Goodenough et al. (1985) reported that the biologically important region of the $C$. reinhardtii agglutinins is probably located in the globular head region. The biological activity of the $\mathrm{mt}^{+}$(but not the $\mathrm{mt}^{-}$) agglutinin of $C$. moewusii yapensis was susceptible to agents that disrupt the conformation of globular proteins, which makes it reasonable to suggest that in this $\mathrm{mt}^{+}$agglutinin also, the biologically active site is positioned in the globular end of the molecule.

The overall sugar and amino acid compositions of the $\mathrm{mt}^{+}$and $\mathrm{mt}^{-}$agglutinins show, apart from the very high hydroxyproline content of the $\mathrm{mt}^{-}$agglutinin, a certain similarity, and they also resemble the compositions of the $C$. reinhardtii (amino acid) (Collin-Osdoby \& Adair, 1985) and C. eugametos (amino acid and sugar) (Samson et al., 1987) agglutinins. These similarities in form and composition suggest a common ancestry for recognition molecules of this kind in different Chlamydomonas species. 
$\mathrm{N}$-Acetylglucosamine could not be detected in either of the $C$. moewusii yapensis agglutinins, suggesting the absence of $N$-linked sugar chains in these glycoproteins. This contradicts the results of Wiese et al. (1984), who reported that the sexual responsiveness of the $\mathrm{mt}^{+}$gametes of C. moewusii yapensis could be impaired by tunicamycin, a drug which inhibits the biosynthesis of $\mathrm{N}$-linked sugar chains. To explain this discrepancy we probably have to understand more about the molecular basis of the sexual recognition reaction in Chlamydomonas, especially about the incorporation of the agglutinins in the flagellar membrane and about the precise interactions of the agglutinins with their receptors on the flagellar membrane of their sexual partner.

Since the sugar residues seem to be important for the biological activity of the agglutinins (as evidenced by their sensitivity to periodate) these probably also determine the mating-type- and species-specificity of the molecules. A remarkable property of the $\mathrm{mt}^{-}$agglutinin of $C$. moewusil yapensis was its resistance to direct periodate attack: only after treatment with phosphatase or sulphatase was its biological activity destroyed by periodate, suggesting phosphorylation and sulphation of important sugar residues, a phenomenon which has not been observed in the $\mathrm{mt}^{+}$ agglutinin or agglutinins of other species. A differential effect was apparent in incubations with exoglycosidases, the $\mathrm{mt}^{+}$agglutinin of $C$. moewusii yapensis being susceptible to $\alpha$-glucosidase and the $\mathrm{mt}^{-}$agglutinin to $\alpha$-mannosidase. Using live cells, Wiese \& Wiese (1975) found that $\mathrm{mt}^{+}$, but not $\mathrm{mt}^{-}$gametes of $C$. moewusii yapensis failed to recognize gametes of the opposite sex after exposure to $\alpha$-mannosidase. This suggests that different carbohydrate groups in terminal positions are important for sexual recognition: only more knowledge about the process can explain apparent contradictions regarding mating-type specificity. A differential susceptibility has also been reported for the $C$. eugametos agglutinins, in which terminal galactose groups seem to be involved in the $\mathrm{mt}^{-}$and terminal mannose residues in the $\mathrm{mt}^{+}$biological activity (Samson et al., 1987). Inactivation of biological activity by the same exoglycosidases could, however, not be found for the $C$. reinhardtii agglutinins (Collin-Osdoby \& Adair, 1985). So the barrier between these sexually incompatible species may depend also on subtle differences in carbohydrate sidechains.

We wish to thank Dr A. J. Meyer and Mr G. M. van Woerkom (Academic Medical Centre, University of Amsterdam) for doing the amino acid analyses, Thijs Doorenbosch for doing some of the initial experiments and Anneke Nederbragt for her help with the sugar analyses.

\section{REFERENCES}

Adair, W. S., Monk, B. C., Cohen, R. \& GoodENOUGH, U. W. (1982). Sexual agglutinins from the Chlamydomonas flagellar membrane. Partial purification and characterisation. Journal of Biological Chemistry 257, 4593-4602.

Clamp, J. R. (1977). A gas-liquid chromatographic approach to the analysis of carbohydrates. Biochemical Society Transactions 5, 1693-1695.

Cohn, E. J. \& Edsall, J. T. (1943). Proteins, Amino Acids and Peptides as Ions and Dipolar Ions. New York: Reinhold Publishing Company.

COLlin-OSDOBY, P. \& ADAIR, W. S. (1985). Characterisation of the purified Chlamydomonas minus agglutinin. Journal of Cell Biology 101, 1144-1152.

Crabbendam, K. J., Klis, F. M., Musgrave, A. \& VAN DEN ENDE, H. (1987). Ultrastructure of the plus and minus mating-type sexual agglutinins of Chlamydomonas egametos, as visualized by negative staining. Journal of Ultrastructure and Molecular Structure Research (in the Press).

Drozdz, M., Kucharz, E. \& SzYJA, J. (1976). A colorimetric micromethod for determination of hydroxyproline in blood serum. Zeitung fuer Medizinische Labortechnik 17, 163-171.

Goodenough, U., Adair, W. S., Collin-Osdoby, P. \& Heuser, J. E. (1985). Structure of the Chlamydo- monas agglutinin and related flagellar surface proteins in vitro and in situ. Journal of Cell Biology 101, 924-941.

Homer, R. B. \& Roberts, K. (1979). Protein conformation in plant cell walls. Circular dichroism reveals a polyproline II structure. Planta 146, 217-222.

Klis, F. M., Samson, M. R., Touw, E., Musgrave, A. \& VAN DEN ENDE, H. (1985). Sexual agglutination in the unicellular green alga Chlamydomonas eugametos. Identification and properties of the mating type plus agglutination factor. Plant Physiology 159, 740746.

LAMPORT, D. T. A. (1980). Structure and function of plant glycoproteins. In The Biochemistry of Plants, vol. 3, pp. 501-541. Edited by J. Preis. New York: Academic Press.

Musgrave, A., Van Eyk, E., Te Welscher, R., Broekman, R, Lens, P., Homan, W. \& VAN DEN ENDE, H. (1981). Sexual agglutination factor from Chlamydomonas eugametos. Planta 153, 362369.

Perkins, S. J., Miller, A., Hardingham, I. E. \& Muir, H. (1981). Physical properties of the hyaluronate binding region of proteoglycan from pig laryngeal cartilage: densitometric and small-angle neutron scattering studies of carbohydrates and 
carbohydrate-protein macromolecules. Journal of Molecular Biology 150, 69-95.

Saito, T. \& MatSUda, Y. (1984). Sexual agglutinin of mating-type minus gametes in Chlamydomonas reinhardtii. II. Purification and characterization of minus agglutinin and comparison with plus agglutinin. Archives of Microbiology 139, 95-99.

Samson, M. R., Klis, F. M., Homan, W. L., Van Egmond, P., Musgrave, A. \& Van den Ende, H. (1987). Composition and properties of the sexual agglutinins of the flagellated green alga Chlamydomonas eugametos. Planta 170, 121-127.

Siegel, L. M. \& MoNTY, K. J. (1966). Determination of molecular weights and frictional ratios of proteins in impure systems by use of gel filtration and density gradient centrifugation. Application to crude preparations of sulfite and hydroxylamine reductases. Biochimica et biophysica acta 112, 346-362.

Smith, S. A. \& SeEgan, G. W. (1984). The pleated sheet: an unusual negative staining method for transmission electron microscopy of biological macro- molecules. Journal of Ultrastructure Research 89 , 111-122.

VAN DEN ENDE, H. (1985). Sexual agglutination in Chlamydomonads. Advances in Microbial Physiology 26, 89-124.

VAN Holst, G. J. \& VARnER, J. E. (1984). Reinforced polyproline II conformation in a hydroxyprolinerich cell wall glycoprotein from carrot root. Plant Physiology 74, 247-251.

WIESE, L. \& JONES, R. F. (1963). Studies on gamete copulation in heterothallic Chlamydomonads. Journal of Cell Comparative Physiology 61, 265-274.

WIESE, L. \& WIESE, W. (1975). On sexual agglutination and mating type substances in isogamous heterothallic Chlamydomonads. Developmental Biology 43, 264-276.

Wiese, L., Hardcastle, A. \& Stewart, H. (1984). Inactivation of the $(+)$ gamete agglutinin during the mating-type reaction in Chlamydomonas. Gamete Research 9, 441-449. 